\title{
Keragaman Komunitas Fitonematoda pada Sayuran Lahan Monokultur dan Polikultur di Sumatera Barat
}

\section{Community Diversity of Phytonematodes on Monoculture and Polyculture Vegetables Farms in West Sumatera}

\author{
Amallia Rosya*, Winarto \\ Universitas Andalas Padang, Padang 25163
}

\begin{abstract}
ABSTRAK
Nematoda parasit tanaman merupakan salah satu patogen yang dapat menimbulkan kerugian dalam budi daya tanaman seledri. Nematoda parasit yang menginfeksi tanaman seledri di antaranya ialah Helicotylenchus spp., Trichodorus, Longidorus, Xiphinema dan Meloidogyne spp. Pola tanam menjadi bagian faktor yang mempengaruhi keberadaan nematoda parasit di tanaman seledri. Penelitian dilakukan untuk menentukan jenis, kepadatan dan kelimpahan nematoda parasit pada tanaman seledri dengan pola tanam monokultur dan polikultur. Sebanyak 7 genus nematoda parasit, yaitu Meloidogyne, Pratylenchus, Tylenchorhinchus, Tylenchulus, Xiphinema, dan dua jenis nematoda nonparasit berhasil teridentifikasi dari daerah dengan pola tanam polikultur, sedangkan dari daerah dengan pola tanam monokultur ditemukan 4 genus, yaitu Meloidogyne, Pratylenchus, Tylenchulus, dan Trichodorus. Genus dengan kelimpahan yang tinggi pada pola tanam polikultur ialah Xiphinema dan Meloidogyne, dan tidak ditemukan Trichodorus. Pada pola tanam monokultur genus dengan kelimpahan yang tinggi, yaitu Meloidogyne dan tidak ditemukan Xiphinema. Frekuensi kehadiran yang tertinggi pada pola tanam polikultur ialah Meloidogyne dan di pola tanam monokultur ialah Xiphinema.
\end{abstract}

Kata kunci: frekuensi kehadiran absolut, kepadatan populasi, seledri

\begin{abstract}
Plant parasitic nematodes can cause crop losses in celery. Parasitic nematodes that infect celery are Helicotylenchus spp., Trichodorus, Longidorus, Xiphinema and Meloidogyne spp Cropping pattern becomes part of the factors that influence the presence of plant parasitic nematodes in celery. Field obervation was conducted in celery growing areas to study the diversity and abundance of parasitic nematodes from monoculture and polyculture cropping system. Seven genus of nematodes, i.e. Meloidogyne, Pratylenchus, Tylenchorhinchus, Tylenchulus, Xiphinema, and two nonparasitic nematode were identified from polyculture cropping system, whereas 4 genus were found from monoculture cropping system i.e. Meloidogyne, Pratylenchus, Tylenchulus and Trichodorus. Genus with high abundance in polyculture cropping pattern was Xiphinema and Meloidogyne however Trichodorus was not found. Genus with a high abundance in monoculture was Meloidogyen and Xiphinema was not found. The genus most frequently found was Meloidogyne in polyculture and Xiphinema in monoculture.
\end{abstract}

Key words: abundance population, celery, frequency absolute presence

*Alamat penulis korespondensi: Jurusan Hama dan Penyakit Tumbuhan, Universitas Andalas, Kampus Limau Manis, Padang 25163

Tel: 0751-72645, Faks: 0751-72645, Surel: amaliarosya@gmail.com 


\section{PENDAHULUAN}

Tanaman seledri (Apium graveolens) merupakan komoditas sayuran yang bernilai ekonomi karena sering diperlukan sebagai penyedap makanan, bumbu masakan dan penghias hidangan (Kasahara dan Hemmi 1995). Salah satu kendala dalam budi daya tanaman seledri ialah gangguan nematoda parasit akar yang dapat menyebabkan penyakit yang serius. Beberapa jenis nematoda dilaporkan dapat menyebabkan penyakit pada tanaman seledri.

Gejala yang disebabkan nematoda parasit akar ialah bengkak akar, pertumbuhan kerdil, klorosis dan layu. Salah satu faktor yang mempengaruhi keberadaan nematoda parasit pada tanaman seledri ialah pola tanam. Pola tanam yang berbeda akan menyebabkan kondisi agroklimat dan iklim mikro tanah yang berbeda pula. Suhu dan kelembapan tanah yang berbeda sangat berkaitan erat dengan kemungkinan terjadinya penyakit-penyakit yang disebabkan oleh nematoda (Schroth et al. 1998).

Budi daya tanaman sayuran di Indonesia umumnya dilakukan dengan pola tanam monokultur dan polikultur. Monokultur adalah sistem budi daya pada suatu areal lahan yang ditanami dengan satu jenis tanaman saja. Polikultur merupakan sistem budi daya tamanan pada suatu areal lahan yang sama dalam satu tahun ditanami dengan beberapa jenis tanaman, baik yang ditanam dalam waktu yang bersamaan atau waktu yang sedikit berbeda. Perkembangan hama dan penyakit cenderung lebih mudah terjadi pada pola tanam monokultur karena sumber makanan bagi hama dan patogen selalu tersedia. Sebaliknya pada pola tanam polikultur yang diikuti dengan rotasi tanaman, dapat memutus siklus hidup hama dan patogen termasuk nematoda (Ricky 2010).

Penelitian ini bertujuan menentukan keanekaragaman dan kelimpahan nematoda parasit pada pertanaman seledri dengan pola tanam polikultur dan monokultur. Pengetahuan mengenai keanekaragaman nematoda dalam kondisi budi daya yang berbeda sangat diperlukan untuk menentukan teknik dan waktu yang tepat dalam pengendalian penyakit tanaman.

\section{BAHAN DAN METODE}

Penelitian dilakukan dari bulan September sampai November 2011. Pengambilan sampel tanah dilakukan pada areal pertanaman seledri di Kecamatan Lembah Gumanti, Kabupaten Solok, Provinsi Sumatera Barat. Pertanaman seledri di Jorong Taluak Dalam dipilih sebagai sampel pola tanam monokultur dan sampel pola tanam polikultur diambil dari pertanaman seledri di Jorong Batu Bagiriak Nagari Alahan Panjang yang ditanam bersama cabai, kubis, bawang daun, dan bawang merah. Pada masing-masing jorong dipilih 2 lokasi pengambilan sampel dan pada tiap-tiap lokasi ditentukan 5 titik sampel.

\section{Teknik Pengambilan Sampel Tanah di sekitar Pertanaman Seledri}

Pengambilan sampel dilakukan dengan menggunakan bor tanah (diameter $5 \mathrm{~cm}$ ) pada kedalaman $15 \mathrm{~cm}$ dengan jarak $10 \mathrm{~cm}$ dari batang tanaman. Pada tiap titik pengambilan sampel diambil sebanyak $294.37 \mathrm{~cm}^{3}$ tanah (berdasarkan rumus Volume $=\pi r^{2} \mathrm{t}$ ). Sampel tanah kemudian dimasukkan dalam kantong plastik yang telah diberi label dan dibawa ke laboratorium.

\section{Ekstraksi Nematoda dari Tanah}

Ekstraksi tanah dilakukan dengan metode corong Baerman yang dimodifikasi. Corong diisi dengan air hingga menyentuh bagian bawah saringan, kemudian dilapisi dengan kertas saring dan tissue, sebagai penyaring butiran-butiran pasir. Volume sampel tanah pada tiap titik sebanyak $294.37 \mathrm{~cm}^{3}$ dikonversi ke bobot menjadi $235 \mathrm{~g}$ dan dimasukkan ke dalam corong Baerman serta diinkubasi selama 3 hari. Suspensi nematoda diambil dan dimasukkan ke dalam cawan agar dan diamati menggunakan mikroskop binokuler.

\section{Pembuatan Preparat}

Cawan agar yang berisi nematoda hasil ekstraksi tanah dilewatkan di atas nyala api bunsen agar nematoda mati. Nematoda yang 
sudah tidak bergerak diambil dengan pipet tetes, dipindahkan ke kaca objek, dan diamati menggunakan mikroskop untuk memilih sampel nematoda yang akan digunakan untuk identifikasi. Nematoda terpilih dipindahkan menggunakan ujung lidi ke kaca objek yang terlebih dahulu ditetesi dengan gliserin. Kaca objek ditutup dengan kaca penutup dan tepinya dilapisi kutek sebagai perekat.

Pembuatan preparat nematoda bertujuan untuk mengawetkan nematoda parasit yang telah didapatkan, selanjutnya preparat tersebut digunakan untuk pengamatan ciri morfologi sebagai karakter untuk identifikasi. Kunci identifikasi nematoda didasarkan pada tiga buku, yaitu Plant Nematology Agricultural Training and Publication Sacramento (Ayoub 1980), Pengantar Nematologi Tumbuhan (Dropkin 1996), dan Nematoda Parasit Tumbuhan di Pertanian Sub Tropik dan Tropik (Luc et al. 1995).

\section{Analisis Kelimpahan dan Kepadatan Nematoda}

Penghitungan kepadatan populasi dan frekuensi kehadiran nematode dilakukan dengan rumus:

Kepadatan populasi nematoda $(\mathrm{K})$

$$
=\frac{\text { jumlah individu suatu genus }}{\text { volume unit sampel }}
$$

Frekuensi kehadiran (FK)

$$
=(\mathrm{a} / \mathrm{b}) \times 100 \% \text {, dengan }
$$

a, jumlah total nematoda yang terkumpul; b, jumlah total satu genus nematoda

\section{Pengamatan Kondisi Pertanaman}

Keadaan tempat penelitian diamati saat pengambilan sampel tanah. Data lapangan yang dikumpulkan meliputi varietas dan umur tanaman, ketinggian tempat, luas lahan, dan dilakukan pengukuran fisika dan kimia tanah. Wawancara dengan petani dilakukan untuk mendapatkan data mengenai praktik budi daya yang dilakukan.

Analisis tanah terutama dilakukan untuk suhu, kadar air, dan $\mathrm{pH}$ tanah. Suhu tanah diukur menggunakan termometer tanah, yaitu dengan cara membenamkan termometer ke dalam tanah lebih kurang $15 \mathrm{~cm}$ dan selama 10 menit. Bobot kering tanah diukur menggunakan metode Gravimeter. Sebanyak $10 \mathrm{~g}$ tanah dikeringkan dengan oven pada suhu $105^{\circ} \mathrm{C}$ selama 24 jam atau sampai bobotnya konstan untuk menentukan kadar air tanah.

$\underset{\operatorname{tanah}(\%)}{\text { Kadar air }}=\frac{\text { bobot basah }- \text { bobot kering }}{\text { bobot kering }} \times 100 \%$

Pengukuran $\mathrm{pH}$ tanah dilakukan dengan metode $\mathrm{H}_{2} \mathrm{O}$ (Elektrometik). Sebanyak 10 $\mathrm{g}$ tanah dimasukkan ke dalam tabung film dan ditambahkan $10 \mathrm{~mL}$ akuades. Campuran tersebut dicampur selama 30 menit dengan mesin pengocok dan didiamkan selama 2 menit selanjutnya $\mathrm{pH}$ diukur dengan $\mathrm{pH}$ meter.

\section{HASIL}

\section{Kondisi Pertanaman Seledri}

Lahan pertanaman seledri dengan pola tanam monokultur memiliki kondisi lahan yang pemanfaatannya relatif singkat 3-5 tahun. Praktik budi daya menggunakan pupuk buatan, frekuensi penggunaan pestisida jarang, dan $\mathrm{pH}$ tanah netral. Pemanfaatan lahan pada pola tanam polikultur lebih dari 10 tahun. Jenis tanaman yang dibudidayakan lebih beragam, $\mathrm{pH}$ tanah lebih masam, dan pemeliharaan menggunakan pupuk organik dan pestisida lebih sering (Tabel 1).

\section{Kepadatan dan Kelimpahan Nematoda Parasit}

Nematoda parasit yang ditemukan pada tanaman seledri dengan pola tanam monokultur berjumlah 4 genus dan pada pola tanam polikultur ditemukan 6 genus (Tabel 2). Kepadatan nematoda pada pola tanam polikultur sebanyak 0.1517 juvenil per $\mathrm{cm}^{3}$ dan pada pola tanam monokultur 0.2676 juvenil per $\mathrm{cm}^{3}$ (Tabel 3). Genus dengan kelimpahan yang tinggi pada pola tanam polikultur, yaitu Xiphinema dan Meloidogyne serta tidak ditemukan Trichodorus. Pada pola tanam monokultur genus dengan kelimpahan yang tinggi, yaitu Meloidogyne dan tidak ditemukan Xiphinema (Tabel 4). Frekuensi kehadiran yang tertinggi pada pola tanam 
Tabel 1 Kondisi pertanaman seledri di lokasi penelitian di Kecamatan Lembah Gumanti, Kabupaten olok, Provinsi Sumatera Barat

\begin{tabular}{|c|c|}
\hline Pola tanam & Deskripsi lahan \\
\hline $\begin{array}{l}\text { Monokultur } \\
\text { seledri }\end{array}$ & $\begin{array}{l}\text { Lama penggunaan lahan } \pm 1 \text { tahun } \\
\text { Luas lahan } 10 \mathrm{~m} \times 12 \mathrm{~m} \text { dan } 9 \mathrm{~m} \times 15 \mathrm{~m} \text {; Jarak tanam } 5-10 \mathrm{~cm} \\
\text { Rotasi tanaman dengan bawang daun } \\
\text { Pemupukan menggunakan pupuk organik (pupuk kandang berupa kotoran } \\
\text { ayam) dan pupuk buatan (NPK dan SS) } \\
\text { Pengendalian hama dan penyakit dengan pestisida sintetik, } 2 \text { kali seminggu } \\
\text { Suhu rata-rata } 18.6-21.3^{\circ} \mathrm{C} ; \mathrm{pH} \text { tanah } 4.28 \\
\text { Kadar air tanah berkisar } 32.5-42.9 \% \\
\text { Lama penggunaan lahan } \pm 5 \text { tahun }\end{array}$ \\
\hline $\begin{array}{l}\text { Polikultur seledri, } \\
\text { bawang daun, } \\
\text { bawang merah, } \\
\text { cabai, dan kubis }\end{array}$ & $\begin{array}{l}\text { Luas lahan } 45 \mathrm{~m} \times 14 \mathrm{~m} \text { dan } 40 \mathrm{~m} \times 10 \mathrm{~m} \text {; Jarak tanam } 5-15 \mathrm{~cm} \\
\text { Rotasi tanaman dengan kubis dan bawang merah } \\
\text { Pemupukan menggunakan pupuk buatan (Cantik dan Ponska) } \\
\text { Pengendalian hama dan penyakit menggunakan pestisida sintetik, } 1 \text { kali } \\
\text { seminggu } \\
\text { Suhu rata- rata } 18.3-21.3^{\circ} \mathrm{C} \text {; } \mathrm{pH} \text { tanah } 6.07 \\
\text { Kadar air tanah berkisar } 39.9-52.8 \%\end{array}$ \\
\hline
\end{tabular}

polikultur ialah Meloidogyne dan frekuensi kehadiran tertinggi di pola tanam monokultur ialah Xiphinema (Tabel 5).

\section{PEMBAHASAN}

Kepadatan populasi dan kelimpahan nematoda parasit pada pola tanam polikultur tergolong cukup tinggi. Hal tersebut disebabkan semua jenis tanaman yang ditanam merupakan tanaman inang dari nematoda yang ditemukan. Luc et al. (1995) menyatakan bahwa tanaman seledri merupakan inang dari $M$. incognita, $M$ javanica, $M$. thamesi, Trichodorus, Paratylenchus, Longidorus, Xiphinema, Aphelencoides, dan Tylenchus. Bawang merah, bawang putih dan bawang daun merupakan inang dari Ditylenchus. Tanaman kubis merupakan inang dari Longidorus, Xiphinema, Aphelencoides, dan Tylenchorhinchus. Tanaman cabai merupakan inang dari Trichodorus, Paratylenchus dan Tylenchus. Selain nematoda parasit juga ditemukan nematoda predator.

Keberadaan nematoda predator termasuk dalam salah satu pengendalian hayati yang dapat digolongkan sebagai hiperparasitisme. Menurut Altieri dan Nicholls (2004)
Tabel 2 Jenis nematoda pada pertanaman seledri dengan pola tanam monokultur dan polikultur.

\begin{tabular}{ll}
\hline Pola tanam & \multicolumn{1}{c}{ Genus nematoda } \\
\hline Monokultur & $\begin{array}{l}\text { Meloidogyne, Pratylenchus, } \\
\text { Tylenchulus, Trichodorus }\end{array}$ \\
& Meloidogyne, Pratylenchus, \\
& Tylenchorhinchus, Tylenchulus, \\
& Xiphinema, nonparasit \\
\hline
\end{tabular}

kombinasi tanaman yang sesuai pada pola tanam akan meningkatkan keragaman mikroorganisme dalam tanah. Selain itu menciptakan keseimbangan ekosistem dan menstimulasi kehadiran agens hayati.

Koshy et al (2005) menyatakan bahwa pola tanam memiliki pengaruh besar dalam menentukan hubungan antara inang dan nematoda parasitik. Tanaman inang yang ditanam bersama tanaman bukan inang dapat menekan, mengurangi penyebaran dan reproduksi nematoda. Sebaliknya jika tanaman inang dikombinasikan dengan nematoda akan dapat menyediakan makan tanpa terputus bagi nematoda parasitik sehingga reproduksinya akan meningkat.

Semakin lama lahan digunakan maka semakin tinggi populasi nematoda parasit karena tanaman yang ditanam secara terus 
Tabel 3 Kepadatan populasi $\left(\mathrm{ekor} / \mathrm{cm}^{3}\right)$ nematoda parasit pada tanaman seledri dengan pola tanam monokultur dan polikultur.

\begin{tabular}{lrr}
\hline \multirow{2}{*}{ Genus } & \multicolumn{2}{c}{ Pola tanam } \\
\cline { 2 - 3 } & Monokultur & Polikutur \\
\hline Nonparasit 1 & 0.0229 & 0.0305 \\
Nonparasit 2 & - & 0.0196 \\
Meloidogyne & 0.0704 & 0.0739 \\
Pratylenchus & 0.0195 & 0.0257 \\
Trichodorus & 0.0147 & - \\
Tylenchorhinchus & - & 0.0169 \\
Tylenchulus & 0.0242 & 0.0189 \\
Xiphinema & - & 0.0821 \\
\hline Jumlah & 0.1517 & 0.2676 \\
\hline
\end{tabular}

Tabel 4 Kelimpahan genus nematoda parasit pada tanaman seledri dengan pola tanam monokultur dan polikultur (ekor).

\begin{tabular}{lcc}
\hline \multirow{2}{*}{ Genus } & \multicolumn{2}{c}{ Pola tanam } \\
\cline { 2 - 3 } & Monokultur & Polikutur \\
\hline Nonparasit 1 & 28 & 66 \\
Nonparasit 2 & - & 29 \\
Meloidogyne & 104 & 101 \\
Pratylenchus & 29 & 38 \\
Trichodorus & 22 & - \\
Tylenchorhinchus & - & 25 \\
Tylenchulus & 36 & 28 \\
Xiphinema & - & 121 \\
\hline Jumlah & 219 & 405 \\
\hline
\end{tabular}

-, tidak ditemukan nematoda.

Tabel 5 Frekuensi dan kriteria kehadiran nematoda parasit pada tanaman seledri dengan pola tanam monokultur dan polikultur (\%).

\begin{tabular}{lcc}
\hline \multirow{2}{*}{ Genus } & \multicolumn{2}{c}{ Pola tanam } \\
\cline { 2 - 3 } Nonparasit 1 & 60 (Konstan) & 80 (Absolut) \\
Nonparasit 2 & 0 & 50 (Assesori) \\
Meloidogyne & 100 (Absolut) & 80 (Absolut) \\
Pratylenchus & 70 (Konstan) & 60 (Konstan) \\
Trichodorus & 50 (Assesori) & 0 \\
Tylenchorhinchus & 0 & 30 (Assesori) \\
Tylenchulus & 70 (Konstan) & 50 (Assesori) \\
Xiphinema & 0 & 100 (Absolut) \\
\hline
\end{tabular}

Frekuensi dan kriteria kehadiran nematoda (Suin 1997). $\leq 25$, aksidental; >25-50, assesori; >50-70, konstan; > 75, absolut.

menerus masih merupakan kisaran inang nematoda. Penggunaan lahan dengan musim tanam yang lama mengakibatkan beragamnya jenis patogen, salah satunya adalah keragaman nematoda (Vovlas et al. 2008).
Pada pola tanam polikultur digunakan pupuk buatan dan pada pola tanam monokultur digunakan pupuk organik (pupuk kandang, kotoran ayam). Penggunaan pupuk organik dapat mempengaruhi populasi dan keberadaan nematoda. Menurut Vovlas et al. (2008) nematoda menyebabkan kerugian yang nyata pada tanaman seledri. Strategi pengendalian yang digunakan ialah dengan nematisida, solarisasi tanah, bahan organik, pengendalian biologi, tanaman yang tahan nematoda. Hal ini bertujuan mencegah infestasi nematoda pada seledri. Kepadatan populasi dan kelimpahan nematoda juga dipengaruhi oleh penggunaan pupuk.

Sistem pertanian yang dilakukan secara monokultur di lokasi penelitian dan mengabaikan cara-cara bercocok tanam yang benar memberi peluang pada mikroorganisme untuk menginfeksi tanaman. Abawi dan Widmer (2000) melaporkan umumnya semua praktik pertanian yang dilakukan berpengaruh secara langsung maupun tidak langsung terhadap tingkat kejadian dan keparahan penyakit akar yang disebabkan oleh nematoda parasit tumbuhan. Praktik pertanian ini tidak hanya berpengaruh terhadap kepadatan populasi nematoda di dalam tanah, tetapi juga semua hama tanaman dam mikrofauna serta mikroflora yang menguntungkan. Berbagai praktik budi daya pertanian yang kurang tepat telah dilakukan seperti waktu tanam tidak tepat, pemilihan tanaman yang kurang tepat, aplikasi bahan kimia seperti fungisida, insektisida, nematisida, pupuk pada konsentrasi yang sangat tinggi, pengolahan lahan yang terlalu dalam dan sebagainya menyebabkan kerusakan yang luar biasa terhadap pertumbuhan tanaman dan keseimbangan mikroorganisme tanah yang pada akhirnya menimbulkan kerugian ekonomi (Lisnawita 2003).

Nematoda dengan kepadatan populasi dan frekuensi kehadiran yang tinggi pada kedua pola tanam ialah Meloidogyne. Luc et al. (1995) menyatakan bahwa spesies nematoda parasit yang paling banyak di daerah tropik dengan zona iklim panas dan lembap, baik pada dataran rendah dan dataran tinggi, ialah 
Meloidogyne karena inangnya yang banyak dan kemampuan penyebarannya yang luas. Menurut Adnan (2000) Meloidogyne merupakan salah satu nematoda parasit yang bersifat kosmopolit dan memiliki kisaran inang lebih dari 2000 spesies tanaman. Meloidogyne dapat tetap tinggal pada inangnya (sedentary endoparasite). Nematoda endoparasit walaupun inangnya telah rusak, tetapi tetap tinggal pada inangnya sampai mati.

Dari hasil penelitian dapat disimpulkan bahwa terdapat perbedaan keragaman nematoda pada pola tanam polikultur dan monokultur di pertanaman seledri. Selain pola tanam keragaman dan kelimpahan nematoda parasit dipengaruhi oleh praktik budi daya lainnya. Teknik budi daya yang baik dapat menekan populasi nematoda parasit dan salah satu teknik pengendalian.

\section{DAFTAR PUSTAKA}

Abawi GS, Widmer TL. 2000. Impact of soil health manajement practices on soilborne pathogens, nematodes and root diseases of vegetable crops. Appl Soil Ecol. 15(1):3747. DOI: http://dx.doi.org/10.1016/S09291393(00)00070-6.

Adnan AM. 2000. Ketahanan beberapa varietas kedelai terhadap nematoda puru akar (Meloidogyne incognita). Bulletin of Plant Pests and Diseases. 12(1):11-16.

Altieri AA, Nicholls CL. 2004. Biodiversity and Pest Management in Agroecosystems. Food Products Press. New York (US). hlm 236-243.

Ayoub SM. 1980. Plant Nematology Agricultural Training and Publication Sacramento. California (US): Sacramento Nema Aid Publ.

Dropkin VH. 1996. Pengantar Nematologi Tumbuhan. Upratoyo, penerjemah; Yogyakarta (ID): Gadjah Mada University
Press. Terjemahan dari: Plant Nematology Ed ke-2.

Kasahara S, Hemmi S. 1995. Medicinal Herb Index in Indonesia, Ed ke-2. Jakarta (ID): Eisai Indonesia.

Koshy PK, Eapen SJ, Pandey R. 2005. Nematode parasites of spices, condiments and medicinal plants. Di dalam: Luc M, Sikora R, Bridge, Editor. Plant Parasitic Nematodes in Subtropical and Tropical Agriculture. Wallingford (UK): CAB. hlm. 751-91.

Lisnawita. 2003. Pengelolaan tanah sehat dan pengaruhnya terhadap nematoda parasit tumbuhan [skripsi]. Medan (ID): Universitas Sumatra Utara.

Luc MRA, Sikora T, Bridge. 1995. Nematoda Parasit Tumbuhan di Pertanian Sub Tropik dan Tropik. Supratoyo, penerjemah; Yogyakarta (ID): Gadjah Mada Univ. Terjemahan dari: Plant Parasitic Nematology in Tropic and Sub Tropic.

Ricky. 2010. Sistim pola tanam. http:// pertanian.blogspot.com/2010/blog-post. html. [diakses 3 April 2011].

Schroth MH, Istok JD, Connoer GT, Hyman MR, Haggerty R, O'Reilly KT. 1998. Spatial variability in in situ aerobic respiration and denitrification rates in a petroleum-contaminated aquifer. Ground Water. 36(3):924-937. DOI: http://dx.doi. org/10.1111/j.1745-6584.1998.tb02099.x.

Vovlas N, Lucarelli G, Sasanelli N, Troccoli A, Papajova I, Palomares-Rius JE, Castillo P. 2008. Pathogenicity and host-parasite relationships of the root-knot nematode Meloidogyne incognita on celery. Plant Pathol. 57(5):981-987. DOI: http://dx.doi. org/10.1111/j.1365-3059.2008.01843.x. 